\title{
PROBLEMA NASKH DALAM ALQURAN (KRITIK HASBI ASH-SHIDDIQIEY TERHADAP KAJIAN NASKH)
}

\author{
Thoriqul Aziz \\ IAIN Tulungagung Jl. Mayor Sujadi Tim. No.46, Kudusan, Plosokandang, \\ Kedungwaru, Kabupaten Tulungagung, Jawa Timur 66221 \\ Thoriqulaziz11@gmail. com
}

\begin{abstract}
Naskh- mansükh is one of the sciences in Qur'anic sciences that can serve as a 'tool' to understand the messages of the Qur'an. Naskh-mansükh is one of the studies that have long been the subject of dispute among the previous scholars. However, the discussion regarding these manuscripts remains problematic regarding the agreement and inagreement of this issue. The majority of ulama agree that naskh exist in the Qur'an, while several others rejected to its existence. Several Indonesian scholars alo contribute to the debate related to naskh and mansukh. One of them is Teungku Muhammad Hasbi Ash-Shiddieqy. Preliminary finding of this research shows that Hasbi belongs to the second category who reject the existence of naskh in the Qur'an. It is interesting to find out the arguments given by Hasby in defending his view on this issue. This article focus on answering some questions related to:how Hasbi comes to his conclusion that there is no naskh in the Qur'an? How he xplain some verses that categorized by other scholars as nasikh and mansukh? This research employs qualitative method with content analysis to several literatures on the issuebeing researched. This research shows that Hasbi in fact show his strongly rejection to the existence of naskh in the Qur'an. His arguments based on aql (ratio) and naql (text) to criticized his opponent. He argues that there is no verse in the Qur'an catagorised as nasikh mansukh. He further explains the verses fall into the category of takhshis instead of nasikh mansukh.
\end{abstract}

Keywords:

Qur'an ; Naskh-mansūkh , Hasbi as-Siddieqiy.

\begin{abstract}
Abstrak
Naskh-mansūkh merupakan salah satu ilmu dari beberapa ilmu Alquran yang dapat dijadikan sebagai 'alat' untuk memahami pesan-pesan wahyu Alquran. Naskh-mansükh merupakan salah satu kajian yang sudah lama menjadi bahan perbincangan para ulama terdahulu. Akan tetapi, pembahasan terkait naskh-mansükh ini masih menyisakan problem oleh sebagian ulama lain sehingga terdapat pro-kontra dalam menanggapi naskh-mansükh itu sendiri. Selain problem pemahaman atas makna naskh, sebenarnya masih ada lagi problem yang oleh sementara ulama masih mempertanyakan akan "keberadaan" naskh-mansūkh dalam Alquran. Sebagian besar (jumhur) ulama meyakini adanya naskh dalam Alquran sementara sebagian kecil lainnya masih mempertanyakan keberadaanya. Sarjana Indonesia tampak ada yang ikut meramaikan perdebatan kajian naskh tersebut, sarjana itu ialah Teungku Muhammad Hasbi Ash-Shiddieqy. Dalam menanggapi pro-kontra tersebut dengan tegas Hasbi menempatkan posisinya pada kelompok kedua. Lalu pertanyaanya bagaimanakah Hasbi, dalam pemikirannya terkait naskh dapat berkesimpulan seperti itu?Lalu bagaimanakah upaya Hasbi dalam 'mendamaikan' ayat-ayat Alquran yang oleh sebagian ulama mengklaim terdapat naskh dalam Alquran?Jenis penelitian ini adalah kepustakaan (literer). Penelitian ini menemukan kritik Hasbi yang menolak keras akan adanya naskh dalam Alquran. Hasbi mengemukakan argumen-argumen untuk menolak ulama yang mengakui adanya naskh, baik argumen yang berasal dari aql (rasio) maupun naql (teks). Tidak sebatas itu, Hasbi mengkompromikan ayat-ayat Alquran yang dinilai oleh sebagian ulama mengandung nask-mansükhdengan metode tafsir dan takhsis. Sehingga Hasbi menegaskan tidak ada ayat yang naskh atau mansükhdi dalam Alquran.
\end{abstract}

Keywords :

Alquran ; Naskh-mansūkh ; Hasbi as-Siddieqiy.

\section{A. PENDAHULUAN}

Menurut Sahiron Samsuddin dalam sesi perkuliahannya, objek kajian dalam studi Alquran ada empat hal, yaitu Alquran, tafsir, 'ulūm al-Qur'ān, dan living Qur'an. ${ }^{1}$ Salah satu dari keempat objek tersebut yang menjadi fokus perhatian penulis adalah tentang 'ulüm al-Qur'ān . 'ulūm al-Qur'ān ' adalah suatu

\footnotetext{
${ }^{1}$ Perkuliahan penulis dengan Dr. Sahiron Syamsuddin yang menjadi dosen tamu di pasca sarjana IAIN Tulungagung pada hari Sabtu, 23 Desember 2017.
} 
disiplin ilmu yang membahas sesuatu yang berkaitan dengan pemahaman terhadap Alquran. Menurut Muhammad Abu Syahbah dalam al-Madkhal li Dirāsah al-'ulūm alQur'ān al-Karìm, pengertian 'ulüm al-Qur'ān adalah semua hal tentang ilmu pengetahuan yang berhubungan dengan Alquran, baik itu berasal dari dalam Alquran sendiri atau dari luar Alquran. ${ }^{2}$ Dari pengertian tersebut dapat dipahami ada banyak cabang ilmu-ilmu yang terkait dengan Alquran. Dari dalam Alquran semisal tentang 'ilmu asbāb al-Nuzūl, 'ilmu naskh-mansūkh, 'ilmu makkī-madani,dan lain sebagainya. Sementara dari luar Alquran ada 'ilmu rasm, 'ilmu al-qirā'ah, 'ilmu al-balāghah al-Qur'ān, dan yang lainnya.

Istilah 'ulüm al-Qur'ān baru dikenal pada abad ke-3 H, akan tetapi belum menjadi suatu disiplin ilmu tersendiri. Pada dasarnya, embrio akan munculnya 'ulüm al-Qur'ān sudah ada sejak Alquran masih diturunkan pada Rasulullah saw. Para sahabat pada saat itu telah mengenal berbagai macam cabang dari 'ulūm al-Qur'ān semisal 'ilmu asbab alNuzūl, makkì-madanī, naskh-mansūkh dan yang lainnya. Akan tetapi pemahaman para sahabat tersebut belum tersimpan dalam suatu disiplin keilmuan, yakni dalam istilah 'ulüm alQur'ān. ${ }^{3}$

Dalam sejarah perkembangan 'ulūm alQur'ān, ulama berbeda pendapat tentang siapakah yang pertama kali memakai istilah 'ulüm al-Qur'ān sebagai suatu disiplin dalam sebuah keilmuan, atau mungkin salah seorang ulama yang pertama kalinya dalam sejarah menyebutkan dalam suatu karyanya dengan judul 'ulūm al-Qur'ān . Al-Zarqani misalnya, dalam Manāh al-'Irfän fì 'ulūm alQur'ān -nya, mengklaim bahwa orang pertama yang menggunakan istilah 'ulüm al-Qur'ān dalam kitabnya adalah Ali bin Ibrahim bin Sa'id al-Haufiy yang wafat pada $430 \mathrm{H}$,

\footnotetext{
${ }^{2}$ Tim Forum Karya Ilmiah RADEN, Al-Qur'an Kita: Studi Imu, Sejarah, dan Tafsir Kalamullah. (Kediri: Lirboyo Press, 2011),Hlm.2.

${ }^{3}$ Tim Forum Karya Ilmiah RADEN, Al-Qur'an Kita: Studi Imu, Sejarah, dan Tafsir Kalamullah ,Hlm.3.
}

dengan kitabnya yang berjudul al-Burhān fi 'ulūm al-Qur'ān . Al-Zarqani menolak pendapat ulama lain yang menyatakan istilah 'ulūm al-Qur'ān muncul pada abad keVII $\mathrm{H}$, dan ia menggantinya pada abad ke-4 $\mathrm{H}$ dengan adanya al-Hufiy. ${ }^{4}$ Selain itu masih banyak ulama -ulama lain yang menyatakan pendapat-pendapatnya mengenai pencetus awal 'ulūm al-Qur'ān seperti al-Suyūthi yang mengklaim Abd al-Rahmān bin 'Umar alBulqini wafat pada $824 \mathrm{H}$ dengan kitabnya Mawāqi' al-'Ulūm min mawāqi' al-Nujūm , Shubhi al-Ṣālih menyatakan dalam Mabāhits fi 'ulüm al-Qur'ān orang pertama kali yang menulis 'ulüm al-Qur'ān ialah Muhammad bin Khalāf bin Marzuban yang wafat pada $309 \mathrm{H}$, dengan kitabnya yang berjudul alHầì fi 'ulüm al-Qur'ān ${ }^{5}$ dan lain-lain.

Terlepas dari sejarah kemunculan dan perkembangan 'ulüm al-Qur'ān di atas, penulis tidak bermaksud untuk membahas panjang lebar mengenai seluk beluk tentangnya, melainkan penulis hanya sedikit memaparkan salah satu cabang dari 'ulüm alQur'ān itu sendiri, yakni pembahasan mengenai naskh-mansükh . Naskh-mansükh merupakan salah satu ilmu dari beberapa ilmu Alquran yang dapat dijadikan sebagai 'alat' untuk memahami pesan-pesan wahyu Alquran. Naskh-mansükh merupakan salah satu kajian yang sudah lama menjadi bahan perbincangan para ulama terdahulu. Akan tetapi, pembahasan terkait naskh-mansükh ini masih menyisakan problem oleh sebagian ulama lain sehingga terdapat pro-kontra dalam menanggapi naskh-mansükh itu sendiri.

Kajian naskh menjadi topik hangat dalam penafsiran Alquran, ayat-ayat yang dinilai kontradiksi dengan ayat yang dating belakangan harus dihapus dari peredaran dan digantikan dengan ayat yang 'baru' meskipun

\footnotetext{
${ }^{4}$ Muhammad 'Abdul 'Adzim al-Zarqani, Manāh al-'Irfān fî̀ 'Ulūm al-Qur'ān,terj. H.M. Qadirun Nur Ahmad Musyafiq, (Jakarta: Gaya Media Pratama, 2002),Hlm 27.

${ }^{5}$ Shubhi Shalih. Mabāhis fì 'Ulūm al-Qur'ān, terj. Tim Pustaka Firdaus, (Beirut: Dār al-'Ilm al-Malāyin, 1977), Hlm.159.
} 
ayat tersebut bertentangan dengan realitas sekarang. Dan hal inilah yang menjadi salah satu problem dalam kajian naskh. Selain itu, permasalahan paling mendasar naskh terletak pada pendefinisian makna dari naskh itu sendiri. Pada dasarnya ulama terdahulu dalam pembahasannya terkait naskh, kata naskh merupakan kata yang musytarak (kata yang tidak hanya mempunyai satu makna) sehingga pemahaman naskh begitu luas. Muhammad Amin Suma, seperti yang dikutip oleh Qasim Nurseha, juga mengatakan bahwa di antara kajian Islam tentang hukum (fiqh-ushul fiqh), yang sampai sekarang masih debatable dan kontroversial adalah persoalan naskh, terutama jikadihubungkan dengan kemungkinan adanya naskh-mansūkh antar ayat-ayat Alquran. ${ }^{6}$

Suatu contoh dalam pemahaman ayat-ayat damai yang berlawanan dengan ayat-ayat perang. Dalam hal ini, yang menjadi problem adalah sebagian ulama yang memahami makna naskh dengan makna "menghapuskan", sehingga dalam konteks ayat tersebut ayatayat damai yang notabene turun lebih dahulu (makkī) harus terhapus oleh ayat-ayat perang (madanî). Hal ini menjadi problem serius umat Islam era sekarang, karena mau tidak mau ketika ulama dahulu dalam menetapkan hokum berimbas pada keberlangsungan hidup di pentas dunia ini.

Sementara keterkaitannya hubungan dengan agama lain, naskh masih menjadi perdebatan karena banyak ayat-ayat Alquran yang dinilai menjadi polemik. Banyak ayat-ayat Alquran yang bernada polemik, seperti halnya kedatangan Islam dalam kancah dunia ini ialah sebagai kelanjutan ajaran yang di bawa oleh Ibrahim. Sehingga hal ini membawa kesan bahwa agama Islam yang notabene datang belakangan dari kedua agama samawi sebelumnya Yahudi dan Nasrani. Ayat-ayat tersebut oleh sebagian orang muslim dijadikan

\footnotetext{
${ }^{6}$ Qasim Nurseha Dzulhadi, "Kontroversi Nasikh Mansukh dalam Al-Qur'an”, dalam Tsaqafah, Vol. 5, No. 2, Dhulqa'dah 1430, Hlm.257-258.
}

sebagai 'bukti teks' untuk memenangkan agamanya di atas agama yang lainnya. ${ }^{7}$

Selain problem di atas, sebenarnya masih ada lagi problem oleh sementara ulama yang masih mempertanyakan akan "keberadaan" naskh-mansükh dalam Alquran. Sebagian besar (jumhur) ulama meyakini adanya naskh dalam Alquran sementara sebagian kecil lainnya masih mempertanyakan keberadaanya. Kedua kelompok tersebut mempunyai pandangan yang berbeda dalam menanggapi naskh sehingga keduanya saling 'beradu' argumen tentang keabsahan naskh dalam kajian Alquran. Kelompok yang mengakui naskh seperti al- Syafi' i (w. 204 H. ), alNaḥās (w. 388 H. ), al-Suyūthi (w. 911 H. ) dan al-Syaukani (w. 1280 H. $)^{8}$ dan lain-lain. Sementara kelompok kedua ini dipelopori oleh Abu Muslim al-Ashfahaniy (w. 322 H), alFahrur Rozi (w. 606 H. ) yang kemudian didukung oleh sarjana-sarjana kontemporer seperti Muhammad Abduh $(1325 \mathrm{H})$, dan muridnya Muhammad Rasyid Ridha (1354 H), selain itu ada Muhammad Abu Zahrah (1898-1974), Muhammad al-Ghazali (19171996), Muhammad Husain ad-Dzahabi (1914-1977). ${ }^{9}$

Dari kedua kelompok di atas tampak hanya para sarjana dari luar Negara Indonesia, akan tetapi sarjana Indonesia tampak ada yang ikut meramaikan perdebatan kajian naskhtersebut, sarjana itu ialah Teungku Muhammad Hasbi Ash-Shiddieqy (selanjutnya dipanggil Hasbi). Hasbi adalah seorang sarjana asal Aceh. Hasbi adalah seorang ulama dan cendekiawan muslim. Hasbi ahli dalam ilmu fikih, hadis, tafsir, dan ilmu kalam. Ia juga seorang penulis yang produktif, dan pembaharu (mujaddid)

\footnotetext{
${ }^{7}$ Mun'im Sirry, Polemik Kitab Suci: Tafsir Reformasi atas Kritik al-Quran Terhadap Agama Lain, terj.Cecep Lukman Yasin (Jakarta: Gramedia, 2013), Hlm.61-62.

8 Subaidi, "Historisitas Nasikh Mansukh dan Problematikanya dalam Penafsiran al-Qur'an”, dalam Hermeneutik, Vol. 8, No. 1, Juni 2014,Hlm. 65.

9 M. Quraish Shihab, Kaidah Tafsir: Syarat, Ketentuan, dan Aturan yang harusAnda Pahami dalam Memahami al-Qur'an, (Jakarta: Lentera Hati, 2013), Hlm.286.
} 
yang terkemuka dalam menyeru kepada umat, agar kembali ke Alquran dan Hadis Rasulullah saw. ${ }^{10}$ Hasbi pernah ditunjuk oleh pemerintah Indonesia sebagai tim penerjemah Alquran pada tahun 1967 bersama dengan para pakar yang lain seperti Bustami A. Gani, Muchtar Yahya, Mukti Ali, KH. Ahmad Musaddad, KH. Ali Maksum, dan lain sebagainya. ${ }^{11}$ Oleh karena ketokohannya di bidang ilmu keagamaan sudah tidak diragukan lagi. Oleh karena itu pemikiran Hasbi tentangnaskh menarik untuk ditelusuri. Hasbi menuangkan pemikirannya terkait naskh dalam salah satu karyanya. Dalam menanggapi pro-kontra tersebut dengan tegas Hasbi menempatkan posisinya pada kelompok kedua.

Lalu pertanyaanya bagaimanakah Hasbi, dalam pemikirannya terkait naskh dapat berkesimpulan seperti itu? Lalu bagaimanakah upaya Hasbi dalam 'mendamaikan' ayat-ayat Alquran yang oleh sebagian ulama mengklaim terdapat naskh dalam Alquran?. Selain itu, rasa ingin tahu penulis yang sampai saatini masih belum menemukan titik temu dalam kajian naskh tersebut. Oleh karena hal itulahyang menjadimenarik penulis untuk menelaah sedikit pemikirannya terkait naskh. Sebagai awalanya penulis paparkan pemikiran para ulama yang mengakui adanya naskh dan argumentasinya sebagai pengantar menuju pemikirannya.

\section{B. PEMBAHASAN \\ 1. Pengertian naskh}

Menurut Quraish Shihab, sebagaimana yang dikutip oleh Hasan Asyari Ulama i, menemukan kata naskh di dalam al-Quran dalam berbagai bentuk sebanyak empat kali, yaitu : Qs. al-Baqarah[2]: 106, al-A'raf: 154, al-Hajj[22]: 52, dan al-Jatsiȳah: 29. ${ }^{12}$ Dari

${ }^{10}$ Departemen Pendidikan Nasional, Ensiklopedi Islam, Cet. 9,(Jakarta: PT Ichtiar Baru van Hoeve, 2001), jilid II, Hlm.94.

${ }_{11}$ Taufik Adnan Amal, Rekonstruksi Sejarah AlQur'an (Jakarta: Pustaka Alvabet, 2005), Edidi Digital, Hlm.399.

12 Hasan Asyari Ulama'i, “Konsep Nasikh Mansukh dalam Al-Qur'an”, dalam Didaktika Islamika, Volume 7 Nomor 1 Pebruari 2016, Hlm. 64. segi bahasa kata naskh bermakna, pertama, menukil/menyalin, seperti kalimat nasakhtu al-kitāb (saya menyalin buku) makna kedua menghapus, seperti kalimat nasakhtu al-shams al-dil (matahari menghapus bayangan). Dari kedua makna ini dapat dipahami yang menukil/menyalin atau menghapus dinamakan naskh, sedangkan yang dinukil/disalin atau dihapus dinamakan mansukh. ${ }^{13}$

Sementara Ibnu Mandzur dalam kamus Lisān al-'Arab-nya dituliskan, makna naskh (نسخ) berasal dari nuskhah (نسخة) yang berarti salinan. Dari kata ini muncul beberapa arti seperti al-ibtal (membatalkan), al-tabdil (mengganti), al-naql (memindah), dan alizālah (menghapus atau menghilangkan). ${ }^{14}$ Hampir sama dengan Ibnu Mandzur, alSuyūthi dalam al-Itqān-nya naskh bermakna al-izālah (menghapus atau menghilangkan) dalam hal ini al-Suyūthi berpegang pada Qs. al-Hajj[22]: 52, al-tabdil (mengganti) seperti pada Qs. al-Nạ̣l[16]:101, al-tạwīl (pemindahan) seperti kata al-mirats min wăhid ila wāhìd, al-naql (memindah) seperti kata al-naql min mawādi' ila mawādi'. ${ }^{15}$

Dari beberapa uraian di atas dapat disimpulkan, bahwa yang dinamakan naskh dalam Alquran adalah menyalin, mengganti, memindahkan, menghilangkan atau menghapus ayat yang terlihat bertentangan antara ayat yang satu dengan yang lainnya. Dari hal ini, ayat yang terkena naskh menurut Manna al-Qatan muncul tiga kemungkinan:1) Ayat Alquran di naskh. Baik dari segi bacaan (tilawah) danhukum , sehingga tidak tercantum dalam mushaf seperti penghapusan ayat tentang pengharaman berdasarkan susuan yang awalnya dinyatakan sebanyak 10 (sepuluh kali) susuan diganti dengan 5 (lima) kali susuan. 2) Ayat Alquran di naskh dari segi hukumnva saja, tetapi bacaan (tilawah)

\footnotetext{
${ }^{13}$ M. Quraish Shihab, Kaidah Tafsir.,281.

${ }^{14}$ Ibnu mandzur, Lisān al-'Arab, (Kairo: Dār alMa’ārif, 1119), Hlm.4407.

${ }^{15}$ Jalal al-Din al-Suyuthi, al-Itqān fì 'Ulūm alQur'ān,juz. 2 (Beirut: Dār al-Fikr, 2010), hlm. 326. Lihat juga, Shubhi Shalih. Mabāhis fì 'Ulūm alQur'ān., Hlm. 365-366.
} 
tetap sehingga masih tercantum dalam mushaf. Seperti ketentuan tentang 'iddah (masa tunggu) perempuan yang ditinggal mati suaminya dahulunya selama 1 (satu) tahun (QS. al-Baqarah[2]:240) diganti menjadi 4 (empat) bulan sepuluh hari (al-Baqarah[2]: 234). 3) Ayat Alquran di naskh bacaan (tilawah), tetapi hukumnya tetap, dalam hal ini juga ayatnya tidak tercantum dalam mushaf. Seperti ketentuan hukuman rajam bagi pelaku zina mukhsan (yang berkeluarga). ${ }^{16}$

Dari beberapa makna naskh yang dikemukakan oleh para tokoh di atas tidak hanya satu makna saja, melainkan ada beberapa makna yang melekat pada arti naskh. Dari beberapa makna yang terkandung tersebut para ulama berbeda-beda dalam memahaminya sehingga konsekuensi yang ditimbulkan berbeda pula, seperti halnya contoh yang penulis paparkan di atas. Ulama terdahulu (mutaqaddimin) memandang luas makna naskh, sementara ulama yang datang belakang mempersempit maknanya. Makna itu hanya terbatas pada pengertian pembatalan hukum shar' $i$ akibat munculnya hukum shar'i yang baru yang bertolak belakang dengan yang sebelumnya. ${ }^{17}$

\section{Problem naskh}

Penulis telah menyinggung pembahasan tersebut, kajian naskh dalam Alquran terdapat pro dan kontra. Sebagian besar (jumhur) ulama meyakini adanya naskh dalam Alquran sementara sebagian lagi mempertanyakan keberadaan naskh. Adapun argument pro dan kontra mengenai mengenai naskh yaitu; . ${ }^{18}$

Kelompok pertama berpendapat adanya naskh dengan tiga hal pokok, yaitu sejarah, dalil naql, maupun aql. Pertama, mereka berpedoman pada fakta sejarah sebelum diturunkannya Alquran, yakni penghapusan

\footnotetext{
${ }^{16}$ Manna al-Qaththan, Pengantar Studi Ilmu AlQur'an, terj. Aunur Rafiq (Jakarta: Pustaka al-Kautsar, 2016), Hlm.293-295.

${ }^{17}$ M. Quraish Shihab, Kaidah Tafsir.,hlm.283. Lihat juga Hasan Asyari Ulama'i, “Konsep Nasikh Mansukh dalam Al-Qur'an., Hlm. 65.

${ }^{18}$ Shubhi Shalih. Mabāhis fî̀ 'Ulūm al-Qur'ān., Hlm.371.
}

antarsyari'at terdahulu. Pada dasarnya dalam beberapa aspek syari'at yang dibawa oleh para rasul tersebut kurang lebih sama antara rasul pertama hingga yang terakhir yaitu aspek aqidah, ibadah, dan mu'amalah. ${ }^{19}$ Selain itu tujuan inti dari syariat adalah kemaslahatan bagi umat manusia. Dari hal ini para ulama menyimpulkan lima hal yang wajib terpenuhi pada setiap diri manusia yang disebut dengan al-darüriyyat al-khams, diantaranya: 1) menjaga dan memelihara agama (hifd al-din), 2)menjaga dan memelihara jiwa (hifd alnafs), 3) menjaga dan memelihara akal (hifd al-'aqI), 4) menjaga dan memelihara keturunan (hifd al-nash), 5) menjaga dan memelihara harta (hifd al-mā̄). ${ }^{20}$

Akan tetapi dari setiap diperintahnya seorang rasul terhadap umat yang notabene berada dalam periode atau masa, wilayah yang berbeda-beda, dan tentunya dengan watak manusia itu sendiri yang pada dasarnya juga berbeda. Dengan hal ini maka persoalan yang akan dihadapi seorang rasulpun pasti juga akan berbeda pula. Syariat nabi Musa as misalnya yang lebih dulu ada, hal itu akan berbeda dengan syariat yang di bawa oleh nabi Muhammad saw yang turun lebih belakangan. Akan tetapi tidak semua syariat yang dibawa oleh rasul terdahulu tersebut tidak dapat digunakan pada masa setelahnya, melainkan hanya sebagian saja yang tidak relevan dengan masanya. Oleh karena itu dimunculkannya syari'at kepada para rasul yang terdahulu adakalanya yang terhapuskan oleh syariat yang datang belakangan, demikian menurut Manna al-Qhaththan. ${ }^{21}$ Dari pernyataan inilah, sejarah tersebut dijadikan sebagai bukti bahwa adanya naskh dalam Alquran.

Kedua, mereka yang yakin adanya naskh dalam Alquran berpedoman pada ayat-ayat

\footnotetext{
${ }^{19}$ Manna al-Qaththan, Pengantar Studi Ilmu AlQur'an., Hlm. 284.

${ }^{20}$ Muchlis M. Hanafi, et.all, Maqāssyid alSyari'ah; Memahami Tujuan Utama Syariah, dalam Tafsir al-Qur'an Tematik, (Jakarta: LPMQ, 2013), Hlm. 23.

${ }^{21}$ Manna al-Qaththan, Mabāhis fí 'Ulūm alQur'ān., Hlm.284.
} 
Alquran juga, seperti yang terdapat pada ayatayat berikut ini:

QS.Al-Baqarah[2]: 106

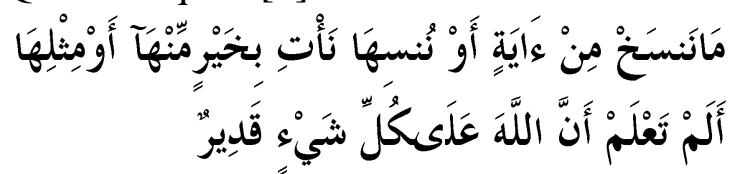

"Ayat mana saja yang Kami nasakhkan, atau Kami jadikan (manusia) lupa kepadanya, Kami datangkan yang lebih baik daripadanya atau yang sebanding dengannya. Tiadakah kamu mengetahui bahwa sesungguhnya Allah Maha Kuasa atas segala sesuatu?"

Qs. al-Nahl[16]: 101

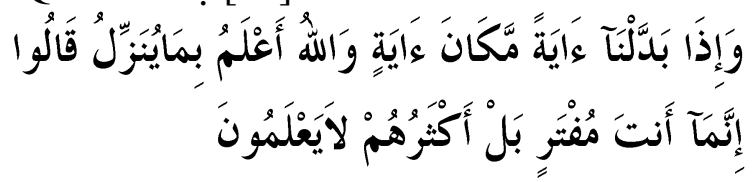

"Dan apabila Kami letakkan suatu ayat di tempat ayat yang lain sebagai penggantinya padahal Allah lebih mengetahui apa yang diturunkan-Nya, mereka berkata: "Sesungguhnya kamu adalah orang yang mengada-adakan saja". Bahkan kebanyakan mereka tiada mengetahui. "

Dari kedua ayat inilah kelompok pertama ini berpegangan. Dalam memahami ayat di atas kelompok ini beranggapan jika ada ayat yang saling bertentangan maka salah satu ayat tersebut naskhyang datangnya belakangan dan yang satunya mansukh ayat yang datangnya terdahulu.

Oleh karena itu para ulama mengakui adanya naskhyang kemudian dalam penelitiannya berkesimpulan ada beberapa ayat yang terindikasi adanya naskh-mansükh, seperti al-Nahhas $(388 \mathrm{H})$ yang mengatakan terdapat 100 ayat dalam Alquran yang termansukh, sementara al-Suyūthi $\mathrm{H}$ )beranggapan hanya ada 20 ayat yang termansukh, lain halnya dengan al-Syaukani $(1250 \mathrm{H})$ yang lebih sedikit memandang ayat yang ter-mansukhia bependapat ayat yang termansukh hanya 8 ayat. ${ }^{22}$

Ketiga, selainargumen di atas, mereka yang pro-naskh mempunyai argumentasi rasional (aql), hal ini sebagaimana dinyatakan Muin Umar yang dikutip oleh Subaidi, argumen itu sebagai berikut. :

Kehendak Allah swt bersifat mutlak, absolut, sehingga Allah swt bebas menyuruh hambanya untuk melakukan sesuatu atau melarangnya. Demikian juga Allah swt bebas menetapkan sebagian hukum-hukumNya atau menghapus (menasakh), karena Allah swt Maha Tahu kemaslahatan terhadap hambaNya dibalik pembatalan tersebut.

Syariat Islam ternyata memerintahkan sesuatu perbuatan yang dibatasi dengan waktu tertentu, seperti puasa Ramadlan, sehingga dengan datangnya bulan syawal berarti perintah puasa terhapus.

Risalah yang dibawa Nabi Muhammad saw diperuntukkankepada umat manusia secara keseluruhan (kafah). Sedang sebelumnya telah ada syariat para Rasul yang terdahulu. Dengan datangnya Islam syariat agama terdahulu terhapus (mansukh). Logikanya, jika tidak ada naskh terhadap hukum syariat, berarti hukum syariat agama yang terdahulu masih berlaku. Jika demikian berarti risalah Islamiyah tidak kafah.

Tidak ada dalil naqli (Nash) yang jelas melarang. Oleh sebab itu logis dimungkinkannya adanya nasakh dan mansukh. ${ }^{23}$

Dari ketiga argumen di atas, terkait dengan sejarah syariat yang pernah ada di dunia ini syariat terdahulu yang diberikan pada rasulrasul sebelum nabi Muhammad saw, semua ulama, baik yang pro atau kontra dengan adanya naskh, bersepakat bahwa dalam pensyari'atan ini terjadi penghapusan atau naskh. ${ }^{24}$

22 Teungku Muhammad Hasbi al-Shiddiqiey, Sejarah dan Pengantar Ilmu al-Qur'an dan Tafsir, Cet. 3,(Semarang: Pustaka Rizki Putra, 2010), Hlm.94.

${ }^{23}$ Subaidi, "Historisitas Nasikh Mansukh dan Problematikanya dalam Penafsiran al-Qur'an", Hlm.66.

${ }^{24}$ M. Quraish Shihab, Kaidah Tafsir., Hlm.283. 
Sementara menurut John Burton, teori naskh ini muncul keterkaitannya dengan pengumpulan Alquran. Menurut Burton, semua riwayat-riwayat pengumpulan Alquran pasca wafatnya Nabi saw tidak dapat dipertanggung jaawabkan untuk mendukung suatu argument yuridis. Konsekuensinya Alquran menjadi pokok pertama hukum Islam yang kemudian disusul dengan hadis. Pokok permasalahan muncul ketika Alquran sudah terkodifikasikan. Ketika ketentuan hukum dalam Alquran muncul tidak sejalan dengan hukum yang ada yang sudah diterima khalayak luas, seperti hukuman rajam bagi pelaku zina seperti yang dikisahkan dalam Qs. Al-Nūr[ 24]: 2. Dalam surat tersebut hukum bagi seorang pezina adalah seratus kali cambuk padahal para fuqaha telah menerima hukum rajam yang telah ada sebelumnya. Hukum rajam adalah syari'at agama sebelum Islam dan juga pernah dipraktikkan pada masa nabi masih hidup, artinya hukum rajam ini tidak ada pertentangan dengan syariat terdahulu. Oleh karena itu fuqaha memunculkan teori naskh atau abrogasi ini. ${ }^{25}$

Akan tetapi yang dipermasalahkan oleh sebagian ulama yang datang belakangan ialah sering mempertanyakan konsep naskh di dalam teks Alquran itu sendiri. Benarkan ada ayat yang harus di hapus dari peredaran karena ayat tersebut tak sejalan dengan realitas, atau mungkin ada kontradiksi dalam Alquran sehingga harus 'mengorbankan' salah satu ayat Alquran dan meninggalkan konsekuensi hukumnya?. Berangkat dari hal itu para ulama pengkritik naskh ini banyak melayangkan argumentasinya sebagai respon terhadap kelompok yang menerima naskh. Argumenargumen kelompok kedua ini yang nantinya sedikit banyak mempengaruhi pemikiran Hasbi Ash-Shiddiqieqy yang selanjutnya nanti penulis paparkan dalam pemikirannya.

Di atas sudah penulis singgung, bahwa Hasbi dalam pemikirannya tentang naskh dengan keras ia menentang terhadap kelompok yang mengakui adanya naskh dalam Alquran. Hal ini dapat dibuktikan dalam salah satu karyanya, Sejarah \& Pengantar Ilmu Alquran dan Tafsir (buku yang di tangan penulis,bukuyang diterbitkan oleh Pustaka Rizki Putra yang sudah dalam cetakan ke-3 pada tahun 2010) dalam buku inilah ia berkata banyak tentang naskh-mansükh .

Sebelum masuk kepada respon Hasbi terhadap argumen-argumen yang dikemukakan kelompok yang pro naskh. Munculnya pengkajian terkait naskh dalam Alquran menurut Hasbi diakibatkan oleh dua hal:

Ditimbulkan dari pembicaraanpembicaraan mengenai naskh hadis. Hasbi mengakui telah terjadi naskh dalam hadishadis maupun sunnah nabi, ataupun sunah nabi dihapuskan oleh Alquran. Ringkasnya, perbincangan naskh telah ada semenjak adanya syari'at.

Para sahabat mempergunakannya perkataan naskh dalam Alquran. Mereka menghendaki dengan naskh, men taqyid kanyang mutlaq, men takhsis kan yang 'amm, dan men tafshil kan yang mujmal. Memang dipahami makna naskh adalah mengangkat. Oleh karena itu sudah ada pembicaraan terkait naskh pada masa ini, baik itu mengenai Alquran maupun sunah. Akan tetapi mengenai ayat Alquran yang diangkat hukumnya, namun ayat tersebut masih terdapat dalam pembacaan/teks-nya masih terdapat dalam Alquran sekarang ini. Para sahabat hanya mendakwa ada sebagian ayat-ayat yang ter nask $h$ dengan sebagian ayat yang lain. ${ }^{26}$

Sementara menurut Quraish Shihab, tidak hanya dua persoalan seperti yang dikemukakan Hasbi di atas, masih ada beberapa faktor yang menyebabkan terdapat adanya naskh-mansükh dalam Alquran yang jumlahnya ratusan, walau tidak semua mereka anggap batal hukumnya. Diantara penyebabpenyebab itu antara lain sebagai berikut:

\footnotetext{
${ }^{26}$ Hasbi al-Shiddiqiey, Sejarah dan Pengantar Ilmu al-Qur'an dan Tafsir., Hlm.99.
} 
Ayat yang mengecualikan atau men-takhsis ayat yang lain.

Ayat yang menerangkan tentang batas akhir pengamalan ayat, jika telah tiba batas akhir berlakunya ayat tersebut. Seperti Qs. alNisā[4]: 15 yang menerangkan seorang wali harus menahan seorang wanita yang berzina di rumahnya, tidak boleh mendatangi tempattempat yang tidak wajar, sebelun nantinya Allah memberikan ketentuan-ketentuan lain terkait dengannya, atau memberikan jalan keluarnya, yakni menikah. Ayat ini dianggap telah ter-mansükholeh Qs. al-NürP[24]: 2 yang menetapkan tentang sanksi dera/cambuk bagi pezina laki-laki maupun perempuan.

Ayat yang kandunganya menyangkut pembatalan terhadap adat yang buruk pada masa jahiliyyah, seperti halnya pembatalan menjadikan anak angkat menjadi anak kandung (Qs. al-Ahzab: 40).

Ayat yang mengandung pembatalan yang menjadi sunnah nabi, seperti pembatalan arah kiblat dari Bayt al-Maqdis diarahkan ke ka'bah (Makkah).

Penjelasan ayat yang satu dengan ayat yang lain, seperti firman-Nya: "Bertaqwalah kepada Allah atas kemampuan kamu” (Qs. alTaghabun: 16), ayat ini menurut mereka dianggap telah ter-naskh dengan ayat:"Wahai orang-orang yang beriman, bertaqwalah kepada Allah dengan sebenar-benar taqwa kepada-Nya” (Qs. Ali “Imran: 2), padahal Qs. al-Taghabun di atas jugamenjelaskan makna "sebenar-benar taqwa kepada-Nya".

Adanya ta'wil atau pengalihan suku kata/susunan kata dari makna satu ke makna yang lain.

Ayat yang memerintahkan untuk bersabar telah di-naskh oleh ayat yang memerintahkan untuk berperang. Kedua ayat tersebut tidak ada yang pertentangan sama sekali, kesabaran dan berperang ada dalam konteks sendirisendiri.

Dari beberapa hal di ataslah yang menjadikan mereka yang meyakini

\footnotetext{
${ }^{27}$ M. Quraish Shihab, Kaidah Tafsir., Hlm.282283.
}

terdapatnya naskh-mansūkh dalam Alquran. Akan tetapi argumen mereka mendapat tanggapan yang keras oleh penentangnya seperti halnya Hasbi. Hasbi dengan lantang menanyakanperihal tersebut adakah dari ayatayat Alquran yang telah dibatalkan hukumnya atau di-mansükh-kan dan tidak wajib dilakukan perintah-perintahnya?Dari pertanyaan inilah, Hasbi mengemukakan pendapat-pendapatnya terkaitnaskh.

Pengertian dan Syarat-syarat naskh ialah adanya pertentangan yang tidak Hasbi dalam mengartikan naskh mengutip dari pendapatnya para ahli fikih, ada dua pendapat yang dikemukakannya: Pertama,hukum yang datang terdahulu dapat dibatalkan oleh hukum yang datangnya belakangan. Seperti hadis nabi yang dahulu pernah melarang para sahabat untuk berziarah kubur namun akhirnya nabi menghapuskan larangan tersebut sehingga membolehkannya.

Kedua, mengangkat umum nashyang telah lalu atau menqaidkan yang muthlaq. Seperti dalam Qs. al-Maidah: 3, "Diharamkan atas kamu (makan) bangkai dan darah" kemudian di dalam surat al-An'am dijelaskan darah yang terpancar. Menurut Hasbi, ayat yang pertama mengenai segala jenis darah merupakan nashyang muthlaq. Sedangkan nashyang kedua mengkaitkan darah yang terpencarpencar menjadi nash muqayyad. Nash yang kedua ini diakui keadaanya dalam Alquran, baik yang demikian dinamakan naskh ataupun dinamai takhsisdan taqyid. Dan yang demikian tersebut tidak berarti membatalkan hukum sama sekali. Sementara makna naskh yang pertama yang mengatakan ada ayat yang dibatalkan hukumnya, akan tetapi ayatnya masih terdapat dalam mushaf, hal inilah menurut Hasbi yang menjadikan titik permasalahan. ${ }^{28}$

Mereka yang mengakui adanya naskh berpegang pada ayat Alquran Qs. alBaqarah[2]: 106 dan Qs. al-Nahl[16]: 101. Selain itu mereka memandang terdapatnya

\footnotetext{
${ }^{28}$ Hasbi al-Shiddiqiey, Sejarah dan Pengantar Ilmu al-Qur'an dan Tafsir., Hlm.100-101.
} 
perbedaan ayat secara lahir dengan ayat yang lain, contohnya 'washiyat dengan ayat mawarits'. Dari adanya ayat yang 'bertentangan' tersebut yang tidak dapat dikompromikan mereka menganggap salah satunya mansükhdan naskh yang datang kemudian.

Menanggapi hal tersebut, Hasbi mengutip pandangan Abu Muslim al-Ashfahani (w. $322 \mathrm{H}$ ): "Jika di dalam Alquran ada ayat yang di-mansukh-kan, berarti telah membatalkan sebagian isinya, membatalkan itu berarti menetapkan bahwa di dalam Alquran itu ada yang batal (yang salah). Padahal Allah berfirman menerangkan sifat Alquran:

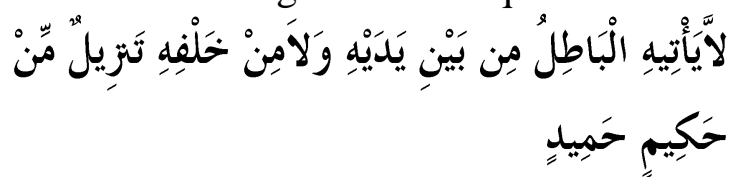

"Tidak datang kepadanya (Alquran) kebatalan, baik di mukanya maupun di belakangnya." (Qs. al-Sajadah: 42).

Hasbi menambahkan, mengingat Alquran itu syari'at yang diabadikan sampai kiamat dan menjadi hujjah bagi manusia sepanjang masa. Oleh karena itu tidak patut sekali terdapat yang mansūkhdi dalamnya. Sunnah boleh din-naskh-kan karena sunnah itu syariat yang sebagianya dating untuk seketika saja, lalu di-naskh-kan dengan sunnah yag dating sesudahnya. Dan mengingat kebanyakan kandungan Alquran bersifat kulliyat bukan juzy-khas. Hukum-hukum di dalamnya diterangkan secara ijmaly bukan secara tafshily. Maka yang baik untuk Alquran mengingat dasar-dassar ini adalah tidak ada ayat yang di-naskh-kan. ${ }^{29}$

Menurut Hasbi, pembatalan ayat-ayat Alquran yang datang belakangan atas ayat yang datang terdahulu harus memenuhi dua faktor: pertama, nashyang datang kemudian me-naskh-kan, yaitu me-naskh-kan yang terdahulu. Kedua, terdapat antara ayat naskh bertentangan yang tidak dapat dikompromikan. Yang demikian itu menurut Hasbi mustahil ada dalam Alquran. Ia

\footnotetext{
${ }^{29}$ Hasbi al-Shiddiqiey, Sejarah dan Pengantar Ilmu al-Qur'an dan Tafsir., Hlm 94-95.
}

menegaskan tidak ada barang suatupun ayat yang me-naskh-kan ayat yang datang terdahulu. Yang sering dijadikan argumen oleh jumhur adalah beberapa ayat seperti Qs. al-Anfal: 65, Qs. al-Muzammil: 17, dan Qs. al-Mujadalah: 12. Ketiga ayat ini menurut jumhur terindikasi naskh, akan tetapi setelah di telisik lebih dalam tidak terdapat naskh. Hasbi membuktikannya, Qs. al-Anfal: 65 tersebut telah diimbangi oleh ayat setelahnya yaitu ayat 66, sementara Qs. al-Muzammil: 17 diimbangi ayat 20 dari surat ini juga, dan terakhir Qs. al-Mujadalah: 12 ayat ini dapat dikompromikan dengan ayat setelahnya juga ayat $13 .{ }^{30}$ Jadi tidak ada satu ayatpun yang bertentangan di dalam Alquran, yang tidak dapat ditakwilkan salah satunya.

Penulis sepakat dengan pendapat Hasbi di atas, di dalam Alquran tidak ada ayat-ayat yang bertentangan antara ayat yang satu dengan yang lain. Jika memang ada yang bertentangan maka itu bukan dari Allah swt. karena Allah sendiri telah menyatakannya dalam Alquran:

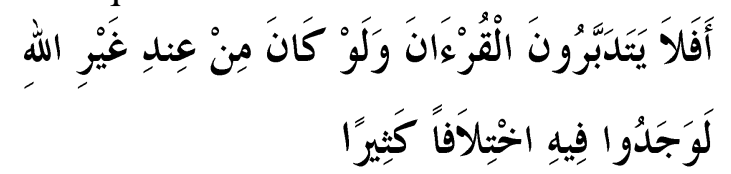

"Maka apakah mereka tidak memperhatikan Al Qur'an? Kalau kiranya Al Qur'an itu bukan dari sisi Allah, tentulah mereka mendapat pertentangan yang banyak di dalamnya. " (Qs. al-Nisā[4]: 82).

Oleh karena ayat ini dengan tegas Allah menyatakanya tidak ada yang bertentangan di dalam Alquran, sehingga tidak mungkin pula ada ayat yang ter-mansukh di dalam Alquran.

Sementara untuk memperkuat pendapat Abu Muslim, Hasbi juga menukil dari pendapat ulama yang kontra dengan naskh, seperti penafsiran Fakhruddin al-Razi. Terdapatnya kata 'ayat' dalam Qs. alBaqarah[2]: 106 di atas tidak harus dimaknai sebagai ayat Alquran saja. Kata 'ayat' tersebut dapat dipahami pula sebagai mukjizat, bukan ayat Alquran. Selain itu kata 'ayat'

\footnotetext{
${ }^{30}$ Hasbi al-Shiddiqiey, Sejarah dan Pengantar Ilmu al-Qur'an dan Tafsir., Hlm 101.
} 
tersebut dapat dipahami sebagai ayat kitabkitab terdahulu yang di-naskh-kan oleh syariat Muhammad. Kemungkinan lain yang dimaksud me-naskh-kan itu adalah memindahkan ayat-ayat dari lauh almahfüdzkepada nabi kemudian ditulis ke dalam mushaf. ${ }^{31}$

Hasbi tidak mengingkari makna naskh selain dengan makna penghapusan saja yang dari makna ini melahirkan kontroversi, selain makna tersebut naskh mempunyai arti menukilkan, akan tetapi jika seandainya berarti mengangkatkan hukum dan dikehendaki dengan ayat adalah ayat Alquran maka hal tersebut hanya menyatakan kemungkinan (kebolehan) naskh, bukan menyatakan hal itu telah terjadi.

Sementara adanya ayat-ayat yang lahirnya bertentangan, menurut Hasbi tidak selamanya menunjuk arti naskh. Menurut Hasbi ayat tersebut dapat ditaufikkan/dikompromikan antara ayat-ayat yang dianggap naskh dengan ayat-ayat yang dianggap mansukh. Dengan sedikit takwilsaja ayat-ayat tersebut dapat didamaikan. Hasbi mencontohkan Qs. alNahl[16]: 101:'Dan apabila kami menggantikan sesuatu ayat di tempat suatu ayat". Menurut Hasbi, kata 'ayat' disini adalah mukjizat. Hal ini dapat dipahami dari susunan kalimatnya. Jika diperhatikan ujung ayat ini, nyatalah kaum musyrik menghendaki ayat, mukjizat yang hissy sebagai mukjizat Luth, Ibrahim, dan Musa. Berkenaan dengan itu Allah berfirman:" Dan apabila Kami gantikan suatu ayat (suatu mukjizat) di tempat suatu ayat (mukjizat) yang lain. ",32

Dari sini dapat dipahami bahwa pendapat Hasbi terkait naskh agaknya tidak sepakat dengan pandangan jumhuryang menyepakati adanya naskh. Dalam pandangannya terkait naskh, Hasbi menolak pendapat jumhur yang berpegang pada dalil naql, seperti yang telah dikemukakan di atas. Dari pendapatnya, dalam mematahkan pendapat jumhur, Hasbi

\footnotetext{
${ }^{31}$ Hasbi al-Shiddiqiey, Sejarah dan Pengantar Ilmu al-Qur'an dan Tafsir., Hlm 95.

${ }^{32}$ Hasbi al-Shiddiqiey, Sejarah dan Pengantar Ilmu al-Qur'an dan Tafsir., Hlm 95.
}

menggunakan metode penafsiran ayat, suatu ayat tidak serta merta diterima secara literal melainkan harus diperdalam lagi untuk memahaminya.

Tidak hanya penafsiran, metode yang lain dalam mendamaikan ayat yang terlihat bertentangan ialah dengan cara mengkompromikannya, entah itu dengan mengkhususkan yang masih umum, memuqayad-kan yang masih muthlaq, dan lainlain. Selanjutnya beberapa metode tersebut yang penulis bahas dalam penjelasan selanjutnya.

Dalam menentukan ayat-ayat naskh menurut Hasbi harus berpegang pada syaratsyarat tertentu, dalam hal ini Hasbi mengutip syarat-syarat tersebut dari pendapatnya Ibnu Hashshar, yaitu:

Nash yang sharih dari Rasul yaitu keterangan dari seorang sahabat dapat dikompromikan serta dapat diketahui sebabsebab turunnya ayat-ayat itu.

Dari beberapa syarat di atas, Hasbi 'mengamini'-nya, syarat-syarat tersebut dijadikan sebagai landasan dasar untuk menentukan kemungkinan adanya ayat-ayat Alquran yang mengandung adanya naskh. Adapun terkait dengan adanya pendapatpendapat para mufasir, mujtahidin, yang mengakui adanya ayat-ayat naskh dengan tegas Hasbi menolaknya. Sebagaimana ungkapannya sebagai berikut:

Tidak boleh dipegang dalam masalah ini pendapat para mufassirin bahkan tidak boleh dipegangi pendapat para mujtahidin, jika tidak ada naqal yang benar atau pertentangan yang nyata. Karena naskh itu mengandung arti yang tetap di masaRasul. Maka untuk mengangkat suatu hukum, mestilah naqal dan tarikh yang menjadi pegangan bukan pikiran dan ijtihad. ${ }^{33}$

Dari pernyataanya di atas, Hasbi dengan lantang menolak naskh yang hanya didasarkan pada pendapat para mufasir ataupun ijtihad para mujtahidin. Hasbi hanya berpegang pada nash yangsharih yang berasal dari nabi ataupun dari ayat yang ada dalam Alquran

\footnotetext{
${ }^{33}$ Hasbi al-Shiddiqiey, Sejarah dan Pengantar Ilmu al-Qur'an dan Tafsir., Hlm.102.
} 
yang nyata terdapat pertentangan dengan ayat yang lain. Dan ini menurut Hasbi 'mustahil', oleh karena itu Hasbi menegaskan, karenanaskh itu mengandung arti pengangkatan hukum atau mengangkat suatu hukum yang telah ditetapkan pada masa Rasul. Maka untuk mengangkat hukum tersebut harus berdasarkan naqal dan tarikh bukan pada pendapat ataupun ijtihad.

Penulis sepakat dengan argumen tersebut, dalam menetapkan naskh memang harus adanya dalil yang sharih atau jelas-jelas dari nabi. Pada dasarnya memang pada masa nabi memang pernah terjadi naskh dalam Alquran, akan tetapi perlu diingat pula pada masa nabi, Alquran belum terkodifikasi dalam bentuk seperti sekarang ini. Adapun yang sekarang ini sudah tidak terdapat lagi ayat-ayat yang di naskhmaupunyang di mansukh. Hal ini juga didukung sebagaimana pada sejarah kodifikasinya Alquran yang pada masa khalifah 'Uthman bin 'affan dalam susunan Alquran sudah tidak mencantumkan lagi ayatayat yang sudah ternaskh. ${ }^{34}$

Terkait dengan pendapat Hasbi yang menolak pendapat para mufasir ataupun mujtahidin yang menetapkan naskh. Hal ini menurut penulis juga masuk akal, karena dari argumen itu terindikasi pertanyaan siapakah yang berhak menaskh ayat-ayat Alquran? Dan karena naskh itu berkaitan dengan hukum yang telah ditetapkan masa Rasul. Tentu jawabanya hanya satu yakni Allah swt, Allah lah yang berhak menaskh kan ayat-ayat yang terdapat dalam Alquran yang notabene ayat tersebut sudah final. Adapun nabi yang pernah mebatalkan hukum yang pernah ada sumbernyapun sama berasal dari Allah swt.

Memang terlihat begitu kolot pemikiran di atas, akan tetapi dalam masalah hukum yang ada dalam realitas yang terus berkembang dan semakin kompleks, bukannya berarti penulis menafikannya. Akan tetapi untuk merespon tantangan tersebut yang semuanya akan dirujuk dalam Alquran, sehingga untuk

\footnotetext{
${ }^{34}$ Muhammad 'Abdul 'Adzim al-Zarqani, Manāh al-'Irfān fì 'Ulūm al-Qur'ān(Jakarta: Gaya Media Pratama, 2002), Hlm.267.
}

memahaminya terdapat kaidah-kaidah yang dapat digunakan. Sehingga dapat digunakan sebagai landasan atas respon terhadap realitas yang kemudian dapat dijadikan sebagai pegangan. Sehingga pemikiran seperti ini tetap mengalir dengan mengikuti realitas dan perkembangan zaman.

Dari pendapat Ibnu Hashshar di atas, Hasbi memberikan pengertian bahwa dalam menetapkan naskh, baik itu hadis yang shahihyang keterangan tersebut asli dari nabi atau adanya pertentangan serta diketahui dalam sejarah keterangan turunnya ayat. Sehingga hadis tersebut dapat dijadikan sebagai argumen untuk menetapkan naskh. Memang ada sebagian hadis yang di-naskh oleh ayat Alquran dan ada yang di-naskh kan oleh hadis-hadis yang lainnya. Lalu pertanyaanya apakah hadis yang dapat menaskh ayat-ayat Alquran ada dalam peredaran kitab-kitab hadis? Maka dengan tegas Hasbi menjawabnya, tidak ada sama sekali. Oleh karena itu, jika ada ayat Alquran yang ternaskh hukumnya, maka mereka wajib menguatkan pendapatnya dengan keterangan yang valid yang berasal dari nabi sendiri. ${ }^{3}$

Hal yang serupa juga diungkapkan oleh Quraish Shihab, dalam menetapkan naskh,yang menjadi pegangan ayat yang me naskh harus lebih kuat daripada yang di naskh, atau sama kuat dengan ayat yang dibatalkan sehingga tidak wajarada ayat Alquran yang dibatalkan dengan hadis, atau hanya dengan ijtihad semata. Kalaupun ada hadis yang yang shahih dan kandunganya terlihat berbeda atau tidak sejalan dengan Alquran, maka hadis tersebut tidak dinilai sebagai membatalkan ayat, tetapi dinilai menjelaskan apa yang dimaksud oleh ayat. Seperti yang terdapat Qs. al-Nisā[4]: 21, yang menerangkan tentang wanita-wanita yang diharamkan untuk dinikahi, ayat tersebut menegaskan "selain mereka halal bagimu" yakni boleh dikawini. Tetapi Rasul saw menyebutkan keharaman menghimpun dalam ikatan perkawinan, dalam

\footnotetext{
${ }^{35}$ Hasbi al-Shiddiqiey, Sejarah dan Pengantar Ilmu al-Qur'an dan Tafsir., Hlm.102.
} 
waktu yang sama, dua orang saudara atau seorang perempuan bersama tantenya. Pernyataan tersebut tidakdisinggung dalam Qs. al-Nisā[4]. Meski demikian, hadis ini menurut Quraish Shihab tidak membatalkan Qs. al-Nisā[4] di atas, tetapi fungsinya sebagai penjelas dari ayat tersebut. ${ }^{36}$

Dari pengertian di atas, baik Hasbi ataupun Quraish Shihab setelah mengemukakan beberapa syarat dan menganalisisnya ternyata syarat-syarat untuk menunjukkan ayat-ayat yang terindikasi naskh ataupun mansükhtidak ditemukan dalam Alquran. Sehingga disini penulis dapat menyimpulkan bahwa ayat Alquran tidak ada yang ter-naskh ataupun termansukh.

Hasbi lebih tegas menyatakan, hal ini dapat dijadikan sebagai dalil untuk menetapkan tidak adanya ayat dalam Alquran yang mansūkhah. Selain itu mereka yang mengklaim adanya ayat yang qath' $i$ telah termasukh oleh sebuah ayat yang lain. Mereka tidak berlandaskan pada hadis yang shahih yang dapat dipandang sebagai nashyang qath'i,yang dikatakan dengan tegas ayat ini ter-mansükholeh ayat yang lain. Hal ini menurut Hasbi sungguh mengherankan karena mereka menganggap ada ayat yang termansūkhakan tetapi tidak berlandaskan dengan dalil yang kuat. Selain itu dalam menetapkan ayat yang ter- mansūkhpun mereka berbeda dalam menentukan jumlah ayatnya. Dari hal ini Hasbimengatakan, bahwa Alquran:

Tidak menerangkan ayat-ayat mansükh. , tidak pula diterima hadis yang menjadi nash yang qath' $i$, para ulama tidak sepakat tentang ayat-ayat yang dipandang mansūkhah dan menetapkan adanya naskh, apabila dapat ditafsirkan, tidak lagi dipandang mansūkhah., tidak pula nyata hikmah adanya yang demikian.

Dari pernyataan di atas, Hasbi menyimpulkanbahwa Alquran yang kita imani, yang kita i'tiqadkan, tidak ada naskh dalam Alquran. Segala ayatnya

\footnotetext{
${ }^{36}$ M. Quraish Shihab, Kaidah Tafsir., Hlm.290.
}

muhkamah,semuanya wajib diamalkan. Oleh karena itu Hasbi memberi 'tantangan' kepada mereka yang mengakui naskh perlu memberikan argumen yang lebih valid. ${ }^{37}$ Lebih lanjut untuk menegaskan tidak adanya naskh dalam ayat Alquran, Hasbi mencoba mengkompromikan ayat-ayat Alquran yang dianggap oleh mereka yang mengakuinya telah ter-naskh atau telah ter- mansükholeh ayat lainnya.

Metode dalam Mendamaikan Ayat-ayat yang Dikatakan terdapat Naskh. Dalam bukunya Sejarah dan Pengantar Ilmu Alquran dan Tafsir, ia menegaskan dalam Alquran tidak ada ayat yang ter-naskh. Dalam hal ini Hasbi 'mendamaikan' ayat-ayat yang oleh alSuyūthi dianggap telah terdapat ayat yang mansükhah sebanyak 20 ayat. Untuk membuktikanya tidak adanya naskh dalam ayat-ayat tersebut Hasbi menggunakan metode Tafsir dan Takhsis.

Kata tafsir secara bahasa menurut Ibn Faris, sebagaimana dikutip oleh Ulinnuha, berasal dari huruf $f a^{\prime}$-sin-ra' yang berarti alkashf (membuka), al-idah (menjelaskan), dan al-bayan (menerangkan). ${ }^{38}$ Dari kata tersebut dapat dipahami mufassir adalah membuka, menjelaskan, dan menerangkan sesuatu yang belum jelas. Definisi tafsir dari segi terminologis adalah: menurut Abù Hayyan sebagaimana di kutip oleh Rosihan Anwar mengatakan bahwa tafsir adalah "ilmu mengenai cara pengucapan kata-kata Alquran serta cara mengungkapkan petunjuk, kandungan-kandungan hukum, dan maknamakna yang terkandung di dalamnya". ${ }^{39}$ Sementara menurut Quraish Shihab yang mengutip dari para pakar adalah penjelasan tentang maksud firman-firman Allah sesuai dengan kemampuan manusia. ${ }^{40}$

\footnotetext{
${ }^{37}$ Hasbi al-Shiddiqiey, Sejarah dan Pengantar Ilmu al-Qur'an dan Tafsir., Hlm.99.

${ }^{38}$ Muhammad Ulinnuha, Rekonstruksi Metodologi Kritik Tafsir, (Jakarta: Azzamedia: 2015), Hlm. 37.

${ }^{39}$ Rosihun Anwar, Ilmu Tafsir. (Bandung: Pustaka Setia. 2005),1 Hlm.42.

${ }^{40}$ Quraish Shihab, Kaidah Tafsir., Hlm.9.
} 
Menurut Hasbi, tidak ada satu ayat Alquran yang tidak dapat ditafsirkan. Sehingga semua ayat Alquran dapat dipahami dengan metode tafsir tersebut. Dalam rangka penafsiran Alquran, menurut Hasbi ialah bertujuan untuk memahami makna-makna Alquran, hukumhukumnya, hikmah-hikmahnya, akhlaqakhlaq, dan petunjuk-petunjuk yang lain untuk memperoleh kebahagiaan dunia dan akhirat. Sehingga nyatalah bahwa manfaat mempelajari tafsir adalah terpelihara dari kesalahan untuk memahami Alquran. ${ }^{41}$

Dalam kaitanya dengan naskh-mansükh, Hasbi menggunakan metode penafsiran untuk mengkompromikan ayat-ayat yang menurut sebagian ulama terindikasi naskh. Diantara ayat-ayat yang dianggap ter-naskh menurut alSuyūthi dan mampu diselesaikan dengan metode tafsir oleh Hasbi diantaranya:Qs. alBaqarah[2]: 180, 187, 217, 240, 284, Qs. Ali Imran: 102, Qs. al-Nisā[4]: 33, 8, Qs. alMaidah: 5, Qs. al-Anfal: 65, Qs. al-NürP[24]: 58, Qs. al-Ahzab: 52, Qs. al-Mujadalah: 12.

Sebagai contoh Qs. al-Baqarah[2]: 284 "Dan jika kamu melahirkan apa yang ada di dalam hatimu atau kamu menyembunyikannya, niscaya Allah akan membuat perhitungan dengan kamu tentang perbuatanmu itu. "Mereka berkata, ayat ini telah di-naskh oleh ayat selanjutnya 286: "Allah tidak membebani seseorang melainkan sesuai dengan kesanggupannya.

Menurut Hasbi, ayat kedua tidak dengan jelas menaskh ayat yang pertama. Allah menghitung perbuatan yang dilakukan manusia,baik lahir maupun batin. Dalam pada itu Tuhan tidak memberatkan manusia melainkan sekedar dengan yang disanggupinya, maka manusia sanggup tidak menyembunyikan kejahatan, sebagaimana sanggup melaksanakan pekerjaan yang ditugaskan mereka untuk mengerjakannya. Dan tidak masuk di dalamnya bisikan-bisikan hati yang terkadang datang dengan tidak disengaja dan hilang tidak meninggalkan

\footnotetext{
${ }^{41}$ Hasbi al-Shiddiqiey, Sejarah dan Pengantar Ilmu al-Qur'an dan Tafsir., Hlm.154.
}

bekasan apa-apa. ${ }^{42}$ Memang secara sekilas terkadang dari segi literal teksnya ayat yang satu dengan yang lainnya terlihat berbeda. Akan tetapi jika kedua ayat tersebut ditelisik lebih dalam akan terlihat titik temunya dan ayat tersebut tidak mungkin bertentangan dengan ayat yang lainnya. Dengan demikian kedua ayat tersebut setelah ditafsirkan tidak ada yang ter-naskh atauter- mansükh.

Takhsis adalah lawan dari 'amm, semua ulama sepakat bahwa yang 'amm dapat dipersempit oleh cakupannya sehingga hanya mencakup sebagian dari cakupan asalnya. Hal ini kalau ada yang mengkhususkannya (mukhashish), mukhashish tersebut bisa merupakan bagian dari rangkaian redaksi (tidak berdiri sendiri) dan bisa juga berdiri sendiri dalam arti ditemukan dalam ayat/hadis atau dalil lain. ${ }^{43}$ Oleh karena itu seseorang dalam memahami ayat-Alquran harus cermat dan jeli. Adapun keterkaitannya dengan naskh-mansūkh sebagian ulama menganggap ayat-ayat amm-khash dimasukan dalam kategori naskh sehingga penetapan ini menjadi fatal.

Oleh karena itu, Hasbi dalam menanggapi klaim yang diberikan oleh sebagian ulama terkait adanya naskh, Hasbi menggunakan metode takhsis tersebut. Hal ini diterapkannya pada ayat-ayat yang menurut al-Suyūthi terdapat naskh-mansükh seperti dalam beberapa ayat berikut: Qs. alBaqarah[2]: 184,Qs. al-Nisā[4]: 15, Qs. alMaidah: 106,Qs. al-NürP[24]: 3, Qs. alTawbah: 41. Sehingga ayat-ayat tersebut dapat dikompromikan dan dengan tegas tidak ada naskh-mansükh dalam ayat-ayat tersebut.

Misalnya dalam Qs. al-Tawbah: 41,:"berangkatlah kamu baik dalam keadaan ringan ataupun berat. "Ayat ini dianggap telah di-naskh-kan oleh Qs. al-NürP[24]: 61:"tidak ada dosa bagi orang buta yang tidak ikut berperang. "Menanggapi hal tersebut, menurut Hasbi, ayat pertama 'amm dan ayat yang kedua menjelaskan orang-orang yang

\footnotetext{
42 Hasbi al-Shiddiqiey, Sejarah dan Pengantar Ilmu al-Qur'an dan Tafsir., Hlm.105-107.

${ }^{43}$ Quraish Shihab, Kaidah Tafsir., Hlm.183-184.
} 
disuruh berangkat kemedan perang dan orangorang yang boleh tidak mengikuti perang. Ringkasnya ayat kedua men-takhsis kan ayat yang pertama, bukan me-naskh kannya. ${ }^{44}$

Dengan demikian dari beberapa ayat-ayat yang telah dianggap terdapat naskh-mansükh nya mampu dikompromikan dengan kedua metode tersebut. Akhirnya penulis dapat simpukan bahwa tidak ada ayat-ayat di dalam Alquran yang ter-naskh maupun ter-mansükh. Wallāhu'alam bi Șawāb.

\section{SIMPULAN}

Perbincangan mengenai naskh dan mansukh dalam Alquran selalu menjadi perdebatan antara kubu yang mengakui akan keberadaan nasikh mansukh tersebut dalam Alquran dengan yang menolak keberadaannya. Salah satu ulama Indonesia, yakni Hasbi al-Shiddieqiy, termasuk ulama yang juga ikut meramaikan perdebatan tersebut. Apabila dikelompokkan dari dualism di atas, maka dapat dipastikan bahwa Hasbi termasuk yang menolak adanya nasikh dan mansukh dalam Alquran. Dalam menanggapi persoalan naskh, Hasbi al-Shiddieqiy mengutip pendapat-pendapat ulama dahulu yang menetang naskh seperti halnya Abu Muslim al-Ashfahani. Selain itu Hasbi juga mengemukakan argumen-argumen 'aqli untuk lebih memperkuat tesisnya yakni menolak naskh. Untuk menguatkan pendapatnya, Hasbi menggunakan metode tafsir dan takhsis untuk membuktikan tidak adanya naskh-mansükh dalam Alquran.

\section{DAFTAR PUSTAKA}

al-Suyuthi, Jalal al-Din. al-Itqān fì 'ulūm alQur’ān ,juz. 2 (Beirut: Dār al-Fikr, 2010) al-Qaththan, Manna. Pengantar Studi Ilmu Alquran, terj. Aunur Rafiq (Jakarta: Pustaka al-Kautsar, 2016)

al-Shiddiqiey,Teungku Muhammad Hasbi.

Sejarah dan Pengantar Ilmu Alquran dan

\footnotetext{
${ }^{44}$ Hasbi al-Shiddiqiey, Sejarah dan Pengantar Ilmu al-Qur'an dan Tafsir., Hlm.109.
}

Tafsir, Cet. 3, (Semarang: Pustaka Rizki Putra, 2010)

al-Zarqani, Muhammad 'Abdul 'Adzim. Manāh al-'Irfān fì 'ulūm al-Qur'ān (Jakarta: Gaya Media Pratama, 2002)

Amal, Taufik Adnan. Rekonstruksi Sejarah Alquran (Jakarta: Pustaka Alvabet, 2005), Edidi Digital

Anwar, Rosihun. Ilmu Tafsir. (Bandung: Pustaka Setia. 2005)

Dzulhadi, Qasim Nurseha. "Kontroversi Nasikh Mansukh dalam Alquran", dalam Tsaqafah, Vol. 5, No. 2, Dhulqa'dah 1430 Hanafi, et. all, Muchlis M. Maqāṣyid alSyarì'ah; Memahami Tujuan Utama Syariah, dalam Tafsir Alquran Tematik, (Jakarta: LPMQ, 2013)

Mandzur, Ibnu. Lisān al-'Arab, (Kairo: Dār al-Ma'ārif, 1119)

Nasional, Departemen Pendidikan. Ensiklopedi Islam, Cet. 9, (Jakarta: PT Ichtiar Baru van Hoeve, 2001), jilid II

RADEN, Tim Forum Karya Ilmiah. Alquran Kita: Studi Imu, Sejarah, dan Tafsir Kalamullah. (Kediri: Lirboyo Press, 2011) Shalih ,Shubhi. Mabāhis fî 'ulūm al-Qur'ān , terj. Tim Pustaka Firdaus, (Beirut: Dār al'Ilm al-Malāyin, 1977)

Subaidi, "Historisitas Nasikh Mansukh dan Problematikanya dalam Penafsiran Alquran", dalam Hermeneutik, Vol. 8, No. 1, Juni 2014

Shihab, M. Quraish. Kaidah Tafsir: Syarat, Ketentuan, dan Aturan yang harus Anda Pahami dalam Memahami Alquran, (Jakarta: Lentera Hati, 2013)

Sirry, Mun'im. Kontroversi Islam Awal: Antara Mazhab Tradisionalis dan Revisionis (Bandung: Mizan, 2015)

Sirry, Mun'im. Polemik Kitab Suci: Tafsir Reformasi atas Kritik al-Quran Terhadap Agama Lain, terj. Cecep Lukman Yasin (Jakarta: Gramedia, 2013)

Ulinnuha, Muhammad. Rekonstruksi Metodologi Kritik Tafsir, (Jakarta: Azzamedia: 2015)

Ulama i, Hasan Asyari. "Konsep Nasikh Mansukh dalam Alquran", dalam 
Didaktika Islamika, Volume 7 Nomor 1

Pebruari 2016 